\title{
THE TRANSPARENCY OF QUALITY AUDITOR SERVICES
}

\author{
Karagod V.S. ${ }^{1}$, Golubeva N.A. ${ }^{2}$, Erokhina E.I. ${ }^{3}$ \\ ${ }^{1}$ Doctor of Economic Sciences, Professor, The National Research Nuclear University "MEPhl", \\ Russia, v.karagod@yandex.ru \\ ${ }^{2}$ Candidate of Economic Sciences, Docent, Peoples' Friendship University of Russia, Russia, \\ golubeva na@pfur.ru \\ ${ }^{3}$ Postgraduate, Peoples' Friendship University of Russia, Russia, erokhinaei@mail.ru
}

\begin{abstract}
The contents of this article are focused on the searching ways of permission of the existing conflict of the public hopes laid on check of auditors and poor quality their carrying out. Problems of standardization of auditor activity in the international community and extent of execution of auditor standards in Russia are carried to the sphere of the conducted research.

The purpose of development is formed recommendations of ways to receive the estimated indicator of quality inspect available to all users of the auditor services.

Results: Has been created the set of the bases for determination of success of the horizon reforms on transition to the International standards of audit in Russia and has been reasonable introduction of the transparent index of quality for each auditor firm.

The practical importance of the received results of this research can be interesting to regulators of auditor activity for any jurisdiction, the professional organizations of auditors and audit organizations in use when forming techniques of external and internal quality control of auditor services.
\end{abstract}

Keywords: assessment quality of audit, audit, audit firm, auditor standards, quality of audit.

\section{INTRODUCTION}

The timeliness of the conducted research which results will be presented in this article is proved by the following factors:

- the auditor scandals which are regularly arising in various jurisdictions and the related loss of trust to audit as to a profession and business practice;

- the difficulties in overcoming long crisis of public and professional regulation of auditor practice in Russia [4], [7] are in many respects caused by the fact that search of an exit from its finds the regulator in consecutive offensive restriction of self-regulation an auditor egregor that has created two-year stressful conditions for the Russian audit. On this background, completion of transition to the international standards of audit (further - ISA), has caused numerous scientific and professional discussions [1], [3], [5], [6] that 
according to Baranov P. P. and Shaposhnikov A.A. (2016) testifies to "substitution of scientific methodology of audit by a substitute set of provisions the auditor standards acquiring the status of a professional doctrine, which are very seldom subjected not that scientific, but even to rational judgment" [2, by Tsit. on]. Without sharing categorical opinions negative or restrictedly negative relation to ISA, authors see in their practical appointment not only the unified complex providing mutual guarantees of agency relationship but requirements on the basis of which auditors can and have to be exposed to the procedure of check both in the egregor and from Society. Proceeding from it, the object of research has determined a complex of the theoretical, methodical and practical questions connected with realization function of external quality control on execution of auditor standards.

\section{SOURCES AND METHODS}

The used methodology consists of a set of procedural methods which using have allowed to stop on observation of realization control execution of auditor standards and problems quality of audit in Russia in historical, institutional, comparative, monographic and analytical approaches to the research.

The data placed in free access have served as the information massif: information of the Ministry of Finance of the Russian Federation; reports of self-regulatory organizations of auditors (further - SROA), the websites of 158 auditor firms (further - AF), data of monitoring the audit market presented by the leading rating agencies of Russia.

\section{RESULTS}

The research of forward establishment and formation the institute of audit has shown that the criterion of ensuring quality rendering auditor services was the motivating response of a professional community to calls of the institutional environment. The authors revealed the interrelation of evolutionary factors: the level of the audit quality is directly dependent on the development of entrepreneurship and the requirements of Society. Tracking the accumulation and transformation in the professional egregore of quality substances from primary audit requirements to professional standards and the principles of the existence an audit in an institutional environment are presented in Fig.1. Fig. 1 schematically shows the periodization of the accumulated integration of experience in assuring the quality of auditing activity in two projections: time and production -market factors corresponded.

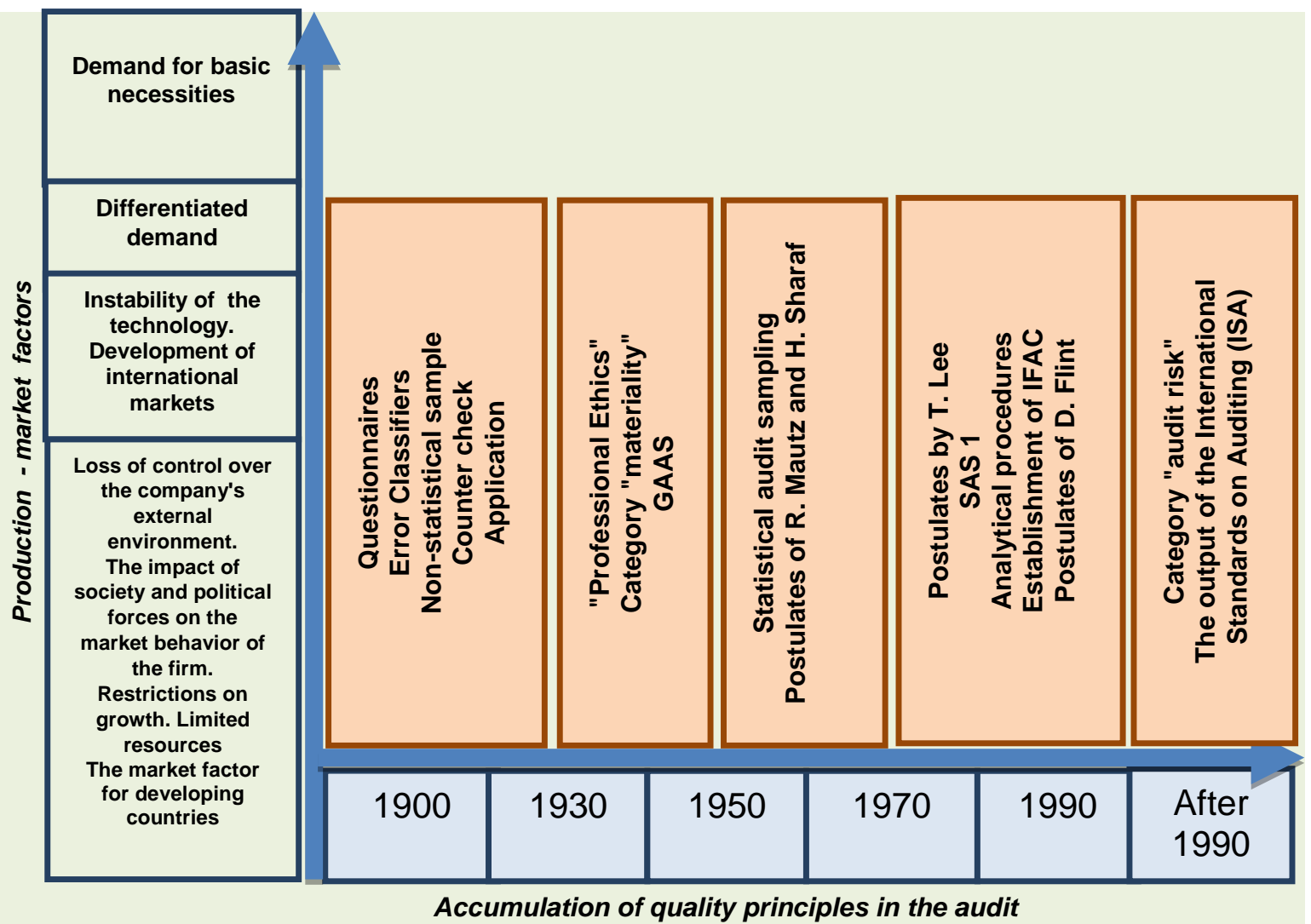

Fig. 1. The retrospective of accumulation qualitative characteristics in audit when entrepreneurial activity 
changes in the 20th century. Source: compiled by the authors

The conditional nature inherent in the chronology of this periodization is due to the degree of prevalence of the accumulated practical approaches in professional auditor circles. It shows the progress of the development qualitative characteristics in the conduct of the audit (methods, methods of organization work, conditions of provision, etc.). The movement's progress towards recognizing the need to move to standardized and unified by other countries approaches of the organization audit activities stretched for two decades. The final milestone in Russia's involvement in international practices in the provision of audit services has become mandatory application since 2017 ISA and final cancellation since 2018 of federal standards of auditor activity.Considering of the study all the pros and cons of the final transition to the ISA, through the renewal of the conceptual provisions regulated by the ISA, in comparison with their previous national variant (FPSAD and FSAD), the coefficient of updating the regulatory and legal base is set at $79.4 \%$.

Analyzing the mass media information on the impossibility fast assimilation new standards by auditors, the authors calculated the duration of assimilation professional changes in auditing for various posts within the $\mathrm{AF}$ and in accordance with the work experience. (See Table 1).

Table 1. Calculation of the period of learning for AF personnel in the course of updating the regulatory framework and ISA

\begin{tabular}{|c|c|c|c|c|}
\hline № & Position & $\begin{array}{c}\text { Work experience } \\
\text { (years) }\end{array}$ & $\begin{array}{c}\text { The period of } \\
\text { assimilation knowledge } \\
\text { (an optimistic version) }\end{array}$ & $\begin{array}{c}\text { The period of assimilation } \\
\text { of knowledge, according to } \\
\text { the "horizon of reforms" }\end{array}$ \\
\hline $\mathbf{1}$ & $\mathbf{2}$ & $\mathbf{3}$ & $\mathbf{4}$ & $\mathbf{5}$ \\
\hline 1 & Partner & From 12 years & 1.5 months & 4 months \\
\hline 2 & $\begin{array}{c}\text { Project } \\
\text { manager }\end{array}$ & From 6 to 11 years & 2.5 months & 11 months \\
\hline 3 & $\begin{array}{c}\text { Auditor-expert } \\
4\end{array}$ & From 2 to 5 years & 4 months & 35 months \\
\hline & $\begin{array}{c}\text { Assistant } \\
\text { Auditor }\end{array}$ & Up to 2 years & 11.5 months & (2 years and 11 months) \\
\hline
\end{tabular}

Source: compiled by the authors

Columns 4 and 5 of this table characterize the time frame for assimilating new requirements. In this case, column 4 is coordinated with the transition period set by the regulator. The transitional period (period of a 2017-2018 year) consists in requiring the regulator to conduct all audits in accordance with the ISA. Column 5 - contains the terms of assimilation, based on the necessary "horizon of reforms" of Edward Lorenz. According to the "horizon of reforms" of Edward Lorenz, the results of the changes should be expected not earlier than 2-3 years. The requirement of the state regulator to speed up the introduction of ISA lays a new foundation for potential risks quality audit services.

In such conditions it is especially important that the interested users of the audit inspections and the conclusions (owners, investors, the public representatives and so forth), could be guided initially in the of the audit market services. It can be realized by means of the imputed duty of each AF which has undergone external testing from the public professional organization of auditors or the state regulator to publish the special indicator of quality on their official internet site. The obligation and reliability of the publication this quality indicator on the official internet site has to be coordinated in the control register of the state regulator. In this case all AF keep on check will seek to provide all documents and practice for obtaining higher value of the quality indicator.

Being guided by good intentions to force AF to struggle for quality of check, the authors considered a number of problems which the success of this project depends. The first problem: the lack of coordination the actions checking quality by the public professional associations and the state regulator. The research showed that the calculated Kendall Concordance Ratio (KCR) is 0.7 , which indicates the average degree of 
consistency between the requirements for external quality control of AF by professional self-regulatory organizations of auditors. It means that as long as the agreement is not reached, the Kendall Concordance Ratio (KCR) will play the role balancing value in the derivation of a single quality measure.

The second problem: the definition of the most frequently violated by the audit organizations regulatory documents that ensure the quality of audit. Using the empirics of the Pareto Law was considered the totality of the reports of the Ministry of Finance of Russia on the audit of external quality assurance of the auditors' work for the period 2008-2016 year. The identified the main $20 \%$ of violations, involving $80 \%$ of defects in the performance of the audit procedures. Then authors have calculated coefficients of ponderability the defects of audit procedures: lack of intra-corporate standards - the administrative regulations providing functioning of quality control of $\operatorname{AF}(0,25)$; violations connected with ignoring of requirements professional development of all employees in $\mathrm{AF}(0,225)$; unfulfillment compulsory procedures when planning the audit inspection $(0,375)$.

The third problem consists in maintaining complex indicator of quality of AF the coefficient of intellectual potential AF (IQ- potential AF). At present, the toolkit for assessing the IQ - potential AF is presented quite widely. The authors do not consider it necessary to recommend any of the variants of the toolkit for assessing intellectual potential, adhering to the position that the IQ - potential AF is very important. The authors would like to emphasize that the IQ-potential AF should reflect the intellectual property of the audit organization or intangible assets, among which: the availability of specialized licenses and certificates for the audit companies whose verification is governed by the additional conditions and restrictions.

\section{CONCLUSIONS}

The conducted research proved that there is a strong link between the quality of audit tools and the level of development of entrepreneurship. The transition to ISA in Russia should be considered logical, despite some difficulties and risks arising from the forcing of the regulator. The authors proposed an integrated approach to the formation of transparent quality indicator that will be determined in the course of external audits in audit firms by public audit organizations and (or) the state regulator. The placement of this quality indicator on official AF websites should provide a reference point for audit services, increase the motivation for quality achievement by audit organizations and make quality control processes for auditing transparent to the public.

\section{REFERENCE LIST}

Azarskaya M.A. (2015). Institutional model of audit. Economic sciences, № 6 (127), p.130-133.

Baranov P.P., Shaposhnikov A.A. (2016). Auditors and fiscals of the era of Peter the Great: the birth of Russian institutions of financial control. Finance and credit, №26, p.28-40.

Gaidarov K.A. (2014). Comparative analysis of federal auditing standards and ISA. General principles of carrying out of audit. "The Auditor", №8 (234), p.34-36.

Nikiforov S.L. (2017). Russian audit: cognitive dissonance (published 2-nd, supplemented).Kazan,160 pages. http://www.acg-pkf.ru/downloads/dwnl144.pdf.

Samoylov E. (2016). 3-4 years will pass and many will leave the audit. Internet resource "Anews". https://www.anews.com/p/51018270-projdet-tri-chetyre-goda-i-mnogie-ujdut-iz-audita/.

Serebryakova T.Y. (2015). International Standards of Auditing as an Object of Research. International Accounting, №4 (346), p. 37-49.

Sheremet A.D. (2017). Some problems of development of audit in Russia. Journal "Audit", №1-2017, p.4-6. 